particulates in the atmosphere. By analysing the polarization of light bouncing off the particles, scientists would have been able to discern their size, shape and chemical make-up - key information for understanding their effect on clouds and global climate. These effects collectively represent the greatest area of uncertainty in current climate models, so scientists have been talking about putting a sensor like this in space for more than a decade.

"The magnitude of the aerosol forcing is a big determinant of where we are going to go in the future," says Gavin Schmidt, a climate modeller at NASA's Goddard Institute for Space Studies in New York. "We have the technology to pin this down more than it is being pinned down, and yet that technology is sitting at the bottom of the ocean."

Glory's failure puts NASA in a quandary. OCO, which would have mapped atmospheric carbon dioxide levels with unprecedented accuracy, enabling scientists to improve definitions of carbon sinks and sources, was deemed so important that the agency planned a rapid-replacement mission. OCO-2 is now scheduled to launch in February 2013 - once again aboard a Taurus XL rocket built by Orbital Sciences. Michael Luther, deputy associate administrator for science programmes at NASA, says the agency will complete the investigation into Glory's failure and then "adjust our plans [for OCO-2] appropriately".

Engineers had determined that the most likely culprit for OCO's failure to reach orbit in 2009 was the system for separating the fairing from the rocket body, which relied on explosives to push the fairing's halves away. After OCO failed, the system was redesigned to use pressurized cold nitrogen gas instead. "We really felt like we had the problem nailed," said Richard Straka, deputy manager of Orbital Science's launch-system group, at a NASA press conference shortly after Glory's launch.

Jonathan McDowell, an astrophysicist at the Harvard-Smithsonian Center for Astrophysics in Cambridge, Massachusetts, who follows rocket launches closely, suggests that Glory's failure might come down to a wiring error. He points out that Orbital Science's Pegasus and Minotaur rockets, which between them have made almost 20 successful launches, use fairings and fairing-release systems similar to those on its Taurus rockets. And because the Taurus had five successful launches between 1994 and 2000 before the string of failures began, $\mathrm{McD}$ owell sees no evidence of a fundamental design problem. "So it's either sloppiness ... or really bad luck." -

Additional reporting by Geoff Brumfiel.

\title{
US scientists in budget limbo
}

\section{Researchers face anxious wait as negotiations continue in Congress over 2011 budget.}

\section{BY EUGENIE SAMUEL REICH}

$\mathrm{T}$ The US Congress narrowly avoided a government shutdown last week by passing a continuing resolution to fund federal activities until 18 March. But the twoweek reprieve is prolonging scientists' anxiety over the final 2011 budget that may emerge from negotiations between the Republicanmajority House and the Democrat-majority Senate. The delay is also raising fears about how drastic the cuts to science might be.

"It's a time of great uncertainty and the [scientific] community is very concerned," says John Marburger, vice-president for research at the State University of New York at Stony Brook. At his university, researchers continue to put in proposals for federal funding, but they worry that a tighter budget will reduce success rates. Marburger, who was science adviser to former president George W. Bush, has spoken out against the cuts proposed by House Republicans. Postdocs and graduate students, who, he estimates, make up $80 \%$ of researchers supported by federal grants, will be hit hardest. "It will put people out on the streets."

The latest continuing resolution cuts US $\$ 4$ billion from federal budgets, although it largely spares science. And if a 2011 budget is eventually agreed, it is unlikely to contain the full $\$ 61$ billion in cuts passed by the House on
19 February, which are not expected to pass the Senate (see 'Budget ping pong'). But House Republicans have said that these proposals will form the basis for future negotiations. Judging by an alternative bill put forward by Senate Democrats on 4 March, the final budget will undoubtedly be lower than 2010 levels.

The uncertainty can be paralysing, says Jennifer Zeitzer, director of legislative affairs for the Federation of American Societies for Experimental Biology (FASEB) in Bethesda, Maryland. "The longer the National Institutes of Health (NIH) is under a continuing resolution, the more people may have questions about their grants," she says. The latest continuing resolution "just kicks the can down the road”. Neurobiologist Darcy Kelley of Columbia University in New York agrees that the mere threat of cuts may be enough to hamper scientists' careers. "With funding levels certain to drop quite drastically, I think people would be even more cautious about hiring somebody new in the lab," she says.

If Congress can't reach agreement in the next two weeks, it will again risk a government shutdown. William Talman, president of FASEB and a neuroscientist at both the University of Iowa and the Veterans Affairs Medical Center in Iowa City, vividly remembers the last government shutdown that began in December 1995. As a physician, Talman was considered to be 'essential personnel' and was funded to care for patients. But his research - a study of neural regulation of blood pressure in rats,

\section{BUDGET PING PONG}

House Republicans and Senate Democrats are battling over federal agencies' 2011 budgets.

\begin{tabular}{|l|l|l|l|l|}
\hline Agency & $\begin{array}{l}\text { House proposed } \\
\text { cut (US\$ million) }\end{array}$ & $\begin{array}{l}\text { \% change } \\
\text { from 2010 }\end{array}$ & $\begin{array}{l}\text { Senate proposed } \\
\text { cut (US\$ million) }\end{array}$ & $\begin{array}{l}\text { \% change } \\
\text { from 2010 }\end{array}$ \\
\hline $\begin{array}{l}\text { Environmental Protection Agency } \\
\begin{array}{l}\text { Centers for Disease Control and } \\
\text { Prevention }\end{array}\end{array}$ & 2,859 & $-28 \%$ & 398 & $-4 \%$ \\
\hline $\begin{array}{l}\text { Department of Energy's Office of } \\
\text { Science }\end{array}$ & 1,397 & $-22 \%$ & 173 increase & $+3 \%$ \\
\hline $\begin{array}{l}\text { National Institute of Standards and } \\
\text { Technology }\end{array}$ & 160 & $-18 \%$ & 162 & $-3 \%$ \\
\hline NASA & 303 & $-19 \%$ & 108 & $-13 \%$ \\
\hline National Institutes of Health & 1,629 & $-2 \%$ & 224 & $-1 \%$ \\
\hline National Science Foundation & 360 & $-5 \%$ & 86 & $-0.3 \%$ \\
\hline
\end{tabular}


funded by the $\mathrm{NIH}$ - came to a grinding halt, because his lab was then located in the government-funded Veterans Affairs Medical Center. "In the labs there was no engineering support, no mechanical support, nothing considered non-essential," he says. "Essentially the labs were in lockdown."

Another temporary funding measure could avert that outcome, but would simply prolong the uncertainty. At the Thomas Jefferson National Accelerator Facility in Newport News, Virginia, a temporary shutdown to upgrade the particle accelerator is scheduled for this year. Robert McKeown, the facility's deputy director for science, had been planning to hire extra people to work on the upgrade, to keep the project on track. But "if the funding situation continues two weeks at a time, I'm afraid we won't be able to make decisions to hire people".

The delay to a finalized 2011 budget also means that any cuts will feel more dramatic when they come. A proposed $18 \%$ cut to the Department of Energy's Office of Science 2011 budget would require a cut of $30 \%$ over the remaining seven months of the fiscal year. At the Thomas Jefferson facility, that would mean the suspension of the accelerator upgrade, McKeown says, and lay-offs for 300 of the roughly 800 staff members working on the site.

Astronomer Scott Tremaine of the Institute for Advanced Study in Princeton, New Jersey - who advised on the National Academy of
Sciences' decadal survey of astronomy and astrophysics priorities in 2010 - says that the uncertainty highlights a major problem of the US system. Budgets are set year-to-year - or, at the moment, fortnight-to-fortnight through congressional negotiations, so longterm, international collaborations are difficult to plan, and assumptions about future budgets are liable to be wrong. For example, the decadal survey worked with figures from NASA projecting a flat budget over the coming decade, and with figures from the National Science Foundation that assumed a doubling of funds relative to a 2007 baseline. Now, says Tremaine, "that is looking unrealistic".

Additional reporting by Meredith Wadman.

\section{Risky energy research faces uncertain future}

\section{ARPA-E's aggressive approach to managing research wins support - but perhaps not federal dollars.}

\section{BY JEFF TOLLEFSON}

$\mathrm{W}$ hen the US energy department's new agency for high-risk, highimpact energy research announced a competition for carbon-capture technologies in December 2009, David Sholl decided to take the plunge. Sholl and his colleagues at the Georgia Institute of Technology in Atlanta had an idea for membranes that make use of a new class of porous crystalline compound to filter carbon dioxide from power-plant exhaust. A month later they had submitted a proposal to the agency, called ARPA-E (Advanced Research
Projects Agency-Energy), and in April 2010 they won a US\$1-million, two-year award.

The first money arrived in July, and two weeks later, Sholl says, his team got a lesson in ARPA-E's hands-on style. "They started calling and saying, 'What have you got done?'” Sholl says. "I'm used to the money-over-the-fence approach with science funding, but this is a much more collaborative sort of relationship." A year into the first round of projects funded by ARPA-E, scientists, businesses and venture capitalists say that the model is already creating a powerful ecosystem that cultivates entrepreneurial science. At least six ARPA-E projects, targeting technologies from solar power to wind energy and batteries, have already gone on to earn additional backing from venture capitalists, and President Barack Obama's administration is eager to scale up the programme. But budget cutting in Congress could stifle the agency before it has a chance to prove itself.

ARPA-E, which received its first funding in 2009, was modelled on the Defense Advanced Research Projects Agency (DARPA), famous for its development of the Internet. Like DARPA, ARPA-E seeks to identify gamechanging ideas that are too radical for agencies such as the National Science Foundation. Its research managers then actively cultivate each project, unlike the hands-off approach taken by basic-research agencies.

The approach leaves little room for serendipity, but Sholl says that it is an effective way to keep research moving and focused on a specific, commercially relevant goal. "One of the huge advantages of the ARPA-E programme is that there is a well-defined industrial target," he says. "ARPA-E is kind of god's gift to venture capital," agrees Matthew Nordan, vice-president of the venture-capital firm Venrock in Cambridge, Massachusetts. "It

\section{ENERGV INVESTMENT | ARPA-E has rolled out grants for more than 100 projects in the past year and a half, ranging from electrofuels (transportation fuels produced from carbon dioxide) to energy-storage technologies for the grid.}

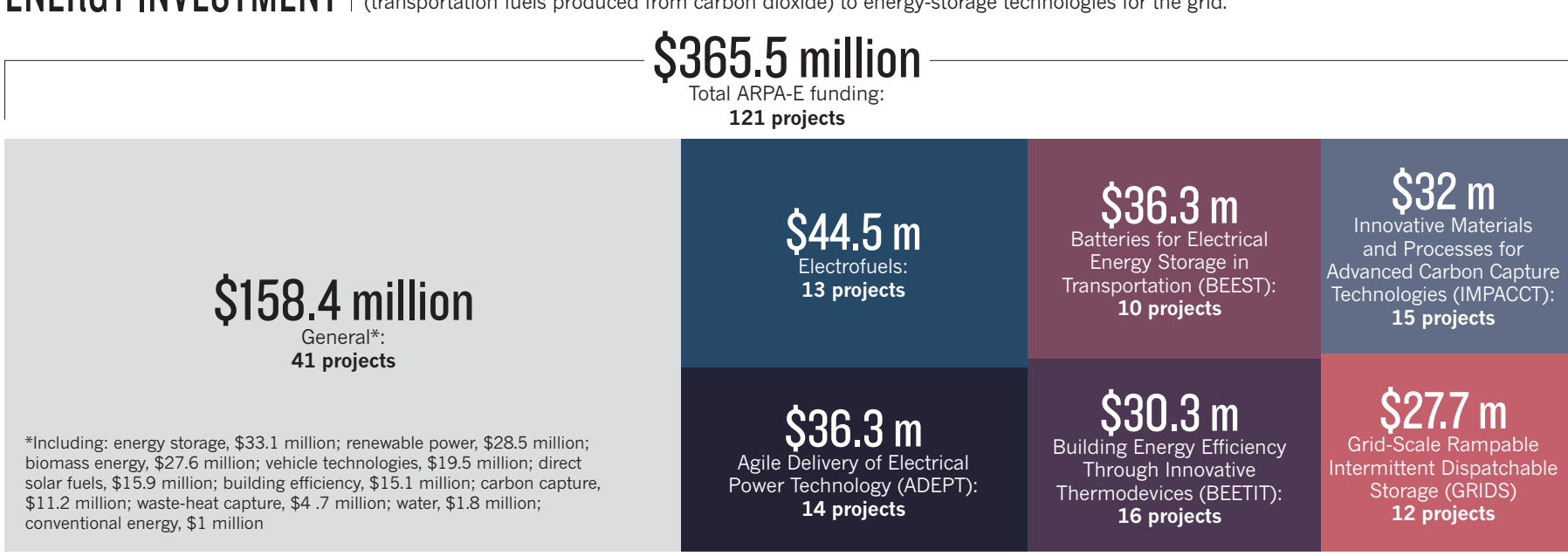

